\title{
Pollination of Byrsonima coccolobifolia: short-distance isolation and possible causes for low fruit production
}

\author{
Amorim, ME. ${ }^{a}$ and De Marco, $P .^{b *}$ \\ aLaboratório de Ecologia Teórica e Síntese, Departamento de Ecologia, Instituto de Ciências Biológicas, \\ Universidade Federal de Goiás - UFG, CEP 74001-970, Goiânia, GO, Brazil \\ 'Laboratório de Ecologia Teórica e Síntese, Departamento de Biologia Geral, Instituto de Ciências Biológicas, \\ Universidade Federal de Goiás - UFG, CEP 74001-970, CP 131, Goiânia, GO, Brazil \\ *e-mail: pdemarco@icb.ufg.br \\ Received June 9, 2010 - Accepted August 30, 2010 - Distributed August 31, 2011
}

(With 3 figures)

\begin{abstract}
Byrsonima coccolobifolia is a tropical plant from the Malpighiaceae family, distributed in the neotropical savanna fields and pollinated by bees known as "collecting-oil bees". In this study, conducted in a Cerrado area located on a farm in the city of Silvânia, GO, the following hypothesis was tested: the greater the isolation degree of a plant, the lower its fruit production due to access difficulties for pollinators. Using a linear regression analysis, it was possible to relate the fruiting rate with the degree of isolation of each $B$. coccolobifolia individual and consequently it was found that the isolation had no influence on the pollination rate, an unexpected event that can be explained by the distance amongst individuals not being large enough to limit the movement of pollinators, or because cross-pollination was not the predominant form of reproduction, since the rate of cross-pollination was similar to self-pollination. It was also found that the proportion of fruits produced was lower than expected, a factor which may also have influenced the results.

Keywords: pollination, isolation, habitat alteration, fruit production.

\section{Polinização de Byrsonima cocolobifolia: isolamento de curta distância e as possíveis causas para baixa produção de frutos}

\section{Resumo}

Byrsonima coccolobifolia é uma planta tropical da família Malpighiaceae, distribuída no Cerrado e polinizada por abelhas conhecidas como "abelhas coletoras-de-óleo". No presente estudo, realizado em área de cerrado localizada em uma fazenda no município de Silvânia, GO, foi testada a hipótese de que quanto maior o grau de isolamento de uma planta, menor sua produção de frutos, devido à dificuldade de acesso dos polinizadores. Através de uma análise de regressão linear foi possível relacionar a taxa de frutificação ao grau de isolamento de cada indivíduo de B. coccolobifolia, e verificou-se que o isolamento não exerceu influência alguma na produção de frutos, fato inesperado que pode ser explicado pela distância entre os indivíduos não ser suficientemente grande a ponto de limitar o trânsito de polinizadores, ou pelo fato da polinização cruzada não ser a forma predominante de reprodução, uma vez que a taxa de polinização cruzada foi semelhante à de autopolinização. Verificou-se ainda que a proporção de frutos produzidos foi abaixo do esperado, fator que também pode ter influenciado os resultados.

Palavras-chave: polinização, isolamento, alteração de habitat, produção de frutos. 


\section{Introduction}

Ecosystems are complex biological structures, consisting of interacting species, arranged according to their functions and processes that are mechanisms directly related to the maintenance of those species (Naeem et al., 1999; De Marco and Coelho, 2004). Ecosystem Services are natural processes that sustain the ecosystem, and can also be used to maintain the quality of human life, especially in agro-ecosystems (Santos et al., 2001; Ricketts, 2004; De Marco and Coelho, 2004). These services involve biological, chemical and geological processes, which include pollination, pest control, seed dispersal, nutrient recycling, water and gas regulation, biological control, genetic resources and the exploitation of "natural beauty" in ecotourism. Thus, the ecosystem services can be defined as material flow, energy and natural "stocks" information, which combined with human activities and manufacturing, produce goods for the human well-being (Kremen et al., 2007; Costanza et al., 1997). A recent estimate showed that ecosystem services average an amount of 33 trillion dollars a year, making decision-making more important than landscape management for conservation and economic development (Costanza et al., 1997).

Pollination is a particularly clear example of a valuable ecosystem service; animal pollinators are essential in the reproduction of about $60-90 \%$ of plant species (Kremen et al., 2007; Ricketts, 2004). The abundance of pollinators and the plant to be pollinated, called by Kremen et al. (2007) a target-plant is influenced by abiotic and biotic factors, including predators, pathogens, parasites and competitors; and by the availability and distribution of resources in their habitat. Therefore, any anthropogenic influences, such as habitat fragmentation, alterations in land use, modern farming practices, the use of chemicals such as pesticides and herbicides, introduction and invasion of plant and animal species (Kearns et al., 1998), can directly affect the pollination systems, drastically altering an entire structure of biotic communities, generating a succession of changes, including the decline of biodiversity (Goverde et al., 2002).

Currently, policies related to land use, especially in tropical areas, have addressed various issues that directly affect the ecosystem services (Vandermeer and Perfecto, 2006). The loss and fragmentation of natural habitats by human activities cause significant effects concerning residing population dynamics (Fahrig, 1998). These effects can bring about a decrease in biodiversity and even lead to local and regional extinction of certain species (Tabarelli et al., 2004). Many recent studies have shown that the diversity and abundance of various taxa in agricultural landscapes decline significantly with increasing distance between the native habitats. In the Neotropics, for instance, Ricketts et al. (2004) found such a decline in moths, Perfecto and Vandermeer (2002) in ants, and Luck and Daily (2003) in birds (Ricketts, 2004).

Landscape modification can change the spatial distribution of plants, which in turn, affects the foraging patterns of pollinators (Cresswell, 1997). If the plant distance is large, pollination could be limited, and the plant fitness can be reduced due to reproductive failure or inbreeding depression, leading to a drop in genetic variability of the population and favoring local extinction. Moreover, according to Andrieu et al. (2009), foraging behavior of some pollinators may be influenced by the amount of available resources and their spatial arrangement. In a fragmented landscape, pollinators may change their foraging mode, and eventually, seek other plant species as a resource according to the new reward/energy expenditure relation. Thus, a change in pollinator behavior can significantly affect the reproductive success, adaptability and even the survival of plants, affecting the dynamics of an ecosystem (Goverde et al., 2002). It is noteworthy that the morphological characteristics of pollinators also influence the foraging pattern. A large-size bee is capable of flying longer distances than a small-sized, thus promoting their search for more isolated resources. In their study, Collevatti et al. (1997) found that the foraging behavior and, consequently, the decision about which flowers to visit, is influenced by: i) body size, which imposes energy requirements and the load of pollen transported on each trip, and ii) flower characteristics, such as the availability of resources and distribution.

The target-plant in this study is Byrsonima coccolobifolia (Kunth.), a tropical tree of the family Malpighiaceae, and like all plants of this genus, and most of the neotropical species of this family, have flowers that instead of nectar, have an abundant lipid composition (oil) (Rezende and Fraga, 2003; Ribeiro et al., 2008). The genus Byrsonima, whose species are known popularly as murici, is distributed in the savanna and the Neotropics (Benezar and Pessoni, 2006). It has some morphological characteristics typical of cerrado plants, usually medium-sized trees reaching $5 \mathrm{~m}$. Its fruit, when ripe, is yellow, with 1.5 to $2 \mathrm{~cm}$ diameter, it has a strong odor, an exotic taste and is rich in vitamins and minerals such as calcium, phosphorus and iron. It is very popular in the North and Northeastern parts of Brazil, and its pulp is commonly used to make juices, wines, liquors and sweets (Rezende and Fraga, 2003; Giraldo-Zuniga et al., 2006; Rego et al., 2006). B. coccolobifolia often occur in areas of open vegetation in South America, with records of its occurrence in Brazil, Bolivia, Venezuela and the Guianas. In the Cerrado of Central Brazil, its flowering period lasts for about two months, starting from September or October and ending in November or December (Sano and Almeida, 1998). Its flowers have sticky pollen grains covered with oil. These are characteristics associated with biotic pollination, because as the secreted oils attract floral visitors who use them as a food source for their offspring, the oils also facilitate the pollen adhesion on their bodies causing them to act as the species pollination agents (Pereira and Freitas, 2002). The pollinators are bees, better known as "oil-collecting bees". Among these groups, the following stand out: the Centridini (Centris and Epicharis), Tapinotaspidini (e.g., Paratetrapedia) and Tetrapediini (e.g. Tetrapedia), all grouped in the Apidae family, and some from the Melittidae family. Amongst these, the 
Centris species stand out because they are considered key pollinators in the maintenance of various plant species in tropical ecosystems, including the Murici (Vinson et al., 1997; Rego et al., 2006; Ramalho and Silva, 2002).

Here, we aimed to evaluate how the distance between plants in natural areas of cerrado, surrounded by a matrix of pasture, is affecting the pollination of Murici (B. coccolobifolia). This hypothesis is important because many areas of Cerrado in the original distribution of B. coocolobifolia are under intense pressure, with increasing fragmentation (Carvalho et al., 2009) that may influence its reproductive efficiency and its ability to persist.

\section{Material and Methods}

\subsection{Study area}

The Cerrado, the second largest Brazilian biome, covers about 2 million $\mathrm{km}^{2}$ (1/4 of the national territory), with $75 \%$ of its area located in the Central Plateau of Brazil. It accounts for about $1 / 3$ of all national biodiversity and $5 \%$ worldwide. Its vegetation includes different savanna, grassland and forest formations (Nomiyama et al., 2000; Ribeiro and Tabarelli, 2002; Sano and Almeida, 1998). A recent study (Carvalho et al., 2009) showed that its fragmentation and habitat loss are not random, thanks to the different land-use options and most of its remnants being preserved only in sloppy areas.

The experiments were performed on two farms. The Vereda farm is owned by the "Consórcio Rio Vermelho" and is located in the rural area of Aragoiânia-GO, on the road GO-219, Km 12. It has a total area of 291,78 ha. Of these, 56,76 ha are considered a legal reserve, a place where the experiment was performed. Fazenda Barreiro is located in the town of Silvania, Goiás, Brazil, and the total area is 2000 ha, mostly for livestock (Figure 1).

The vegetation of the Vereda farm mainly consists of cerrado with small-patches of semi-deciduous forests. The entire area is affected by antropogenic activities nearby which include mining and tourism. On the Barreiro farm, preserved areas reach $25 \%$ of its original land, which includes areas of Cerrado, dry grassland and riparian forest. The distribution of native vegetation is not uniform on the farm, creating the opportunity to test if small-scale tree isolation could affect the pollination process. The selected area for the experiment has a dense vegetation of cerrado sensu stricto, surrounded by a pasture matrix.

\subsection{Visitors of murici}

An initial collection of visitors of $B$. cocoolobifolia flowers was carried out in both areas (Vereda and Barreiro farm). Murici trees were marked and their visitors observed and collected between 7 AM and 12 AM. During this period, an observation period of 10 minutes for each parsed tree was set up and the time and temperature for each sample was recorded. The visitors were collected using entomological nets and preserved in ethyl acetate, stored in paper bags and packed in a freezer to be identified later. Initial taxonomic determination was done using Silveira et al. (2002) and the proper identification made by Dr. Fernando A. Silveira (UFMG).

\subsection{Pollination rate and isolation influence}

This experiment was conducted on the Barreiro farm and included 493 individuals of Byrsonima spp. Each individual was identified to the species level and their geographical coordinates were recorded using a GPS. Flowering status and fruiting status were also noted during plant monitoring.

Three Byrsonima species were present in the area (B. coccolobifolia, B. verbascifolia (Rich.) and B. crassa (Nied.)), but $B$. coccolobifolia was chosen as a target plant due to its high local abundance and flowering time. During the study, only B. coccolobifolia was at the beginning of its flowering period (September). The others either had not started this phase, as is the case of $B$. verbascifolia, or were already at the end of it, such as B. crassa, which in some cases had fruit. Thus, the other Byrsonima species present in the area did not interfere with the ecological processes observed.

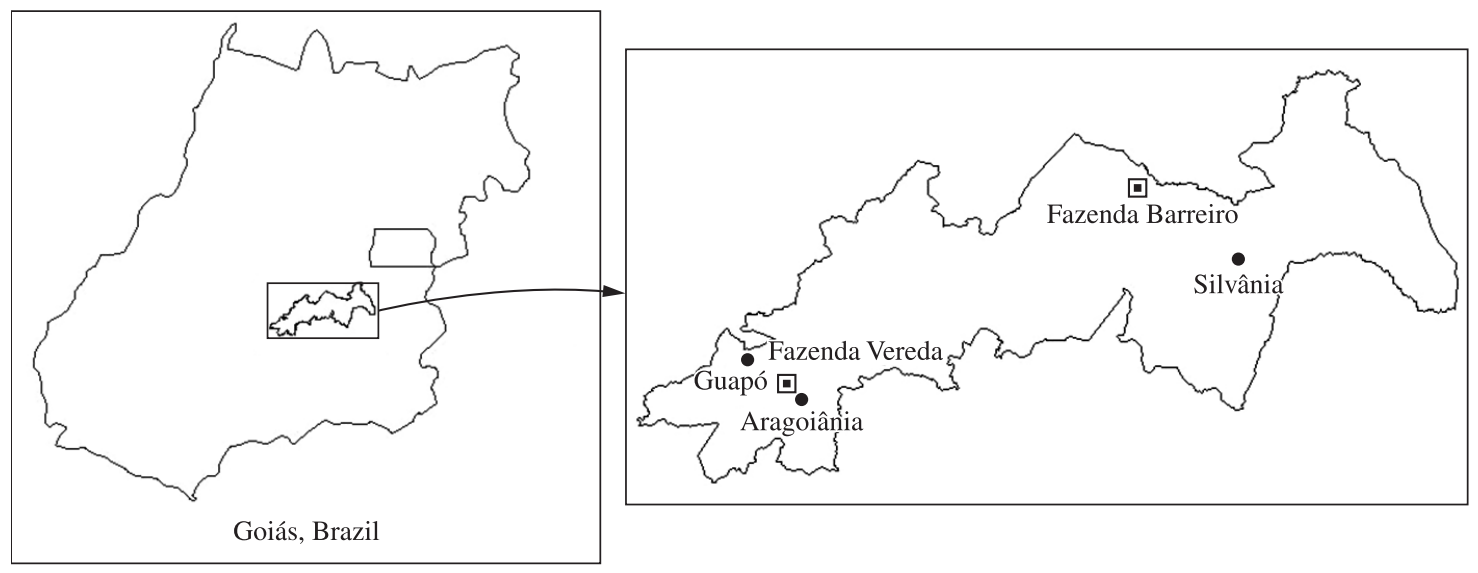

Figure 1. Geographical location of Fazenda Vereda and Fazenda Barreiro - Goiás, Brazil. 
The distribution of all 493 individuals is shown in Figure 2, also showing the 319 individuals of B. coccolobifolia. Some clusters of B. Cocoolobifolia individuals can also be observed. In the northern part of the study area (Figure 2), there is an area with a total absence of Byrsonima, and it is the flattest area lacking trees of any other species, which is a result of intensive grazing in this area. The individuals in the experiment were selected based on the degree of isolation with others in the area. Two individuals were included in the sample due to their isolated distribution in the pasture (Figure 2).

In October 2008, on each selected individual two branches with closed flowers were marked, and the number of flowers recorded. One branch (experimental branch) was wrapped up in a mesh net ( $1.5 \mathrm{~mm}$ pore size) making it impossible for probable pollinators to visit the flowers, but allowing pollen grain passage. The other branch was left unaltered, allowing free access to pollinators (control branch). In the fruiting period, which began in December, the number of fruits on each branch was counted. We noted a large amount of branch breakage in this first evaluation, possibly due to animal predation on the flowers buds. To ensure further evaluation of this effect and to produce an initial account for possible fruit abortion, we returned in January to recount the number of remaining fruits.

We used the distance from the nearest neighbor as an isolation measure for each plant. An alternative measure which may also account for possible autocorrelational effects was the number of individuals around each plant in a radius of 0-10 $\mathrm{m}, 10-25 \mathrm{~m}$ and 25-50 m.

\subsection{Data analysis}

In the following statistical analysis, each individual was considered as a sampling unit. To determine the importance of the pollination agents, we compared the proportion of fruit produced in relation to the number of initial flowering buds in experimental and control branches using a t-test for dependent samples. To test the isolation effect, we used a standard linear regression between the nearest-neighbor distance and the proportion of fruits in the control branch. Similarly, we used multiple linear regression to evaluate the effects of the number of individuals at different radii with the proportion of fruits in the control branch.

\section{Results}

\subsection{Possible pollinators of murici}

The bees collected were identified and fixed obtaining the following results: out of 12 collected bees, 11 are from the Apidae family: 4 workers Paratrigona lineata (Lepeletier), 1 working Tetragonisca angustula (Luiz Juliani), 1 female Centris Centris (Centris) aenea (Lepeletier), 3 females Epicharis (Epicharitides) cockerelli (Friese) and 2 females Paratetrapedia (Tropidopedia) lineata (Spinola);

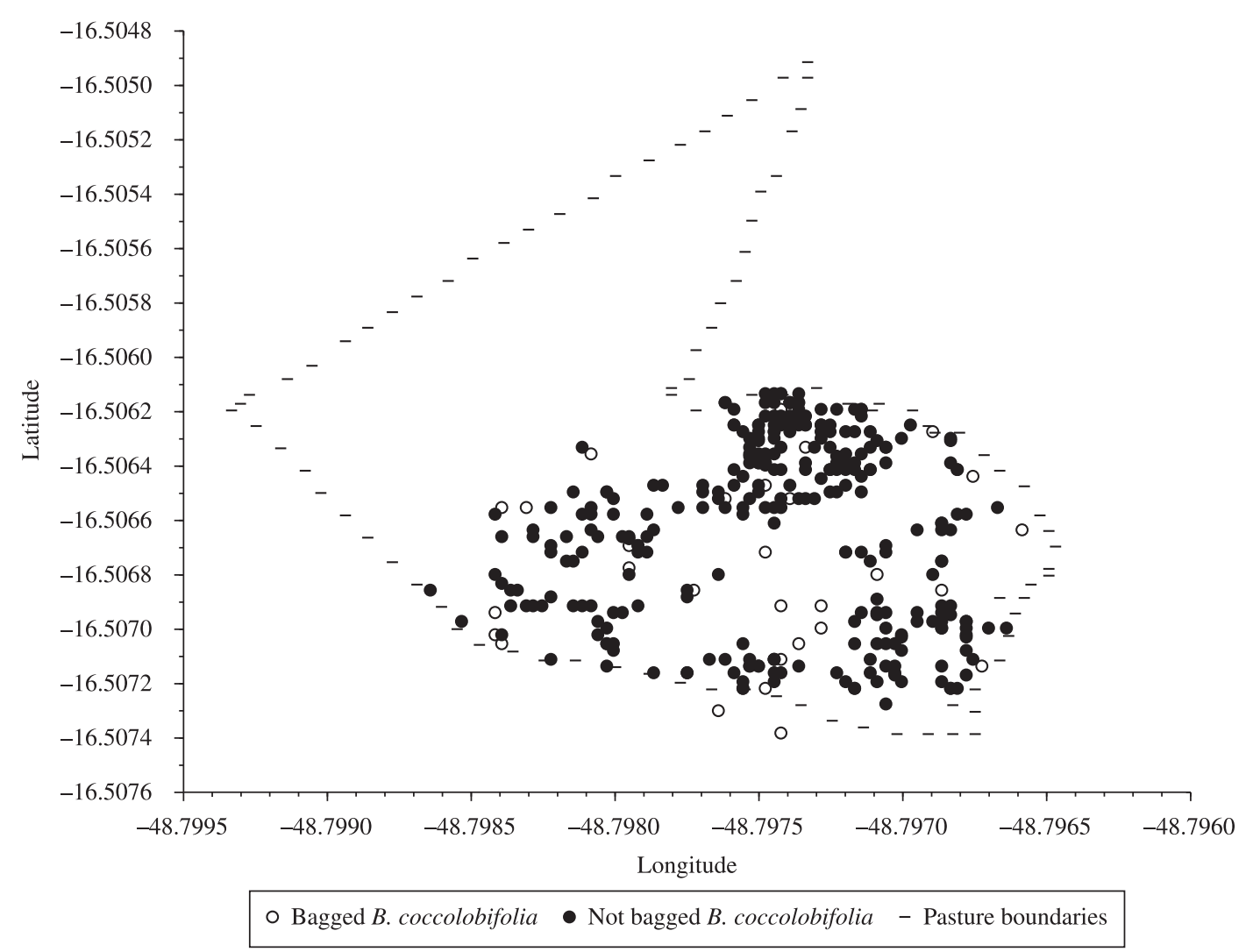

Figure 2. Spatial distribution of B. coccolobifolia within the study area. 
and 1 from the Halictidae family: 1 female Augochloropsis callichroa (Cockerell). This confirms what has been said in the literature about the visitors of Byrsonima being mostly from the Apidae family.

\subsection{Pollination rate and fragmentation influence}

In the first analysis, $t$-test shows that there are no significant differences in the proportion of fruits produced in the treatment and control branches $(t$-test $=-0.90$, $d f=25, \mathrm{p}=0.373$ ), thus not supporting the hypothesis that the plant reproduces mainly by cross-pollination. The results showed that only $5.4 \%$ of the bagged, and $7.2 \%$ of the non-bagged flower produced fruits.

During data collection, it was observed that a significant number of branches was broken. On the first visit to count the amount of fruit produced, out of the 68 marked branches, 9 were broken, which was about $13.2 \%$. In January, the number of broken branches increased to 28 , representing $38.2 \%$ of the total. It is hypothesized that this significant loss of branches may be related to animal movement in the area, bud predation by vertebrates or the result of heavy rains.

Simple regression shows that the distance from the nearest neighbor does not affect fruit production $\left(r^{2}=0.001\right.$, $\mathrm{p}=0.849$ ) (Figure 3). There is also no effect between the number of plants at different radii with fruit production (distance of 0-10 $\mathrm{m}: \mathrm{t}=0.291, \mathrm{p}=0.773,10-25 \mathrm{~m}$ : $\mathrm{t}=-0.597, \mathrm{p}=0.556 ; 25-50 \mathrm{~m}: \mathrm{t}=-0.310, \mathrm{p}=0.759$, as shown in Table 1).

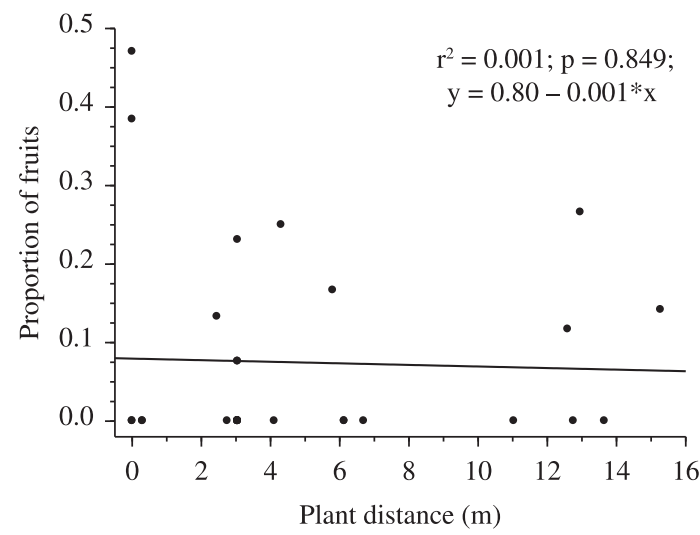

Figure 3. Linear regression enters the distance from the target plant and its nearest neighbor, and the proportion of fruits produced on control branches.

\section{Discussion}

In the field experiments, it could be observed that the flowering periods of the coexisting Byrsonima species differ from each other, which leads us to predict that there is no great influence in the process of pollination on one species over another. This feature may reveal a strategy to avoid competition for pollinators, thereby ensuring the reproductive success of all Byrsonima species in the area.

Comparing the visitors of $B$. coccolobifolia collected in this experiment, with visitors from Byrsonima spp. reported in other studies, we can observe that visitors of this genus predominantly belong to two families: Apidae and Halictidae (Table 2), with a significant number of members from the Apidae. In their study, Barros (1992) found that apparently the bees do not discriminate flowers from different Byrsonima species, which explains the bees' similarities in the different species in question.

The visitors collected in this experiment are medium and small sized bees (Silveira et al., 2002). Body size can influence the foraging patterns of these insects (Collevatti et al., 1997), and Silveira et al. (2002) argue that the dispersal ability varies from species to species. Despite this, large bees, with greater capacity for flight, must disperse much more rapidly than small bees. Thus, the degree of isolation would be a limiting factor in the pollination process mediated by these animals, however the results showed that the rates of isolation did not influence this process. This may have occurred because the mediated pollination by insects was not so important, hiding the effects of isolation, or else, simply because the distance between subjects studied, was not large enough to negatively affect the movement of pollinators.

Various studies show that species of Byrsonima, even though having requirements for cross-pollination, have some degree of self-pollination and self-compatibility (Barros, 1992). However, these studies showed that cross-pollination is predominant in both, B. coccolobifolia, and other species of this genus (Table 3). Thus, the absence of differences in the proportion of fruits produced between experimental and control branches are a result that deserves attention.

Considering the discrepancy of this result with those of other studies and the fact that in evolutionary terms, self-pollination does not appear as a survival strategy, it can be hypothesized that this result may be associated with a deficiency in the attraction and the abundance or dispersal of pollinators. Another plant that blooms at the same time, may compete with the B. coccolobifolia proving

Table 1. Multiple regression analysis of the number of fruits produced and the number of individuals around the target plant at different rays $(0-10 \mathrm{~m}, 10-25 \mathrm{~m}$ and $25-50 \mathrm{~m})-\mathrm{F}_{3.27}=0.203 \mathrm{p}<0.893$ Standard Error estimate: 0.131 .

\begin{tabular}{lcccccc}
\hline & $\beta$ & $\begin{array}{c}\text { Standard } \\
\text { error of } \beta\end{array}$ & $\beta$ & $\begin{array}{c}\text { Standard } \\
\text { error of } \beta\end{array}$ & $\mathbf{t}(\mathbf{2 7})$ & $\mathbf{p}$ \\
\hline Intercept & & & 0.103 & 0.057 & 1.812 & 0.081 \\
R0-10 & 0.071 & 0.245 & 0.001 & 0.005 & 0.291 & 0.773 \\
R10-25 & -0.151 & 0.253 & -0.001 & 0.002 & -0.597 & 0.556 \\
R25-50 & -0.062 & 0.200 & -0.0003 & 0.001 & -0.310 & 0.759 \\
\hline
\end{tabular}




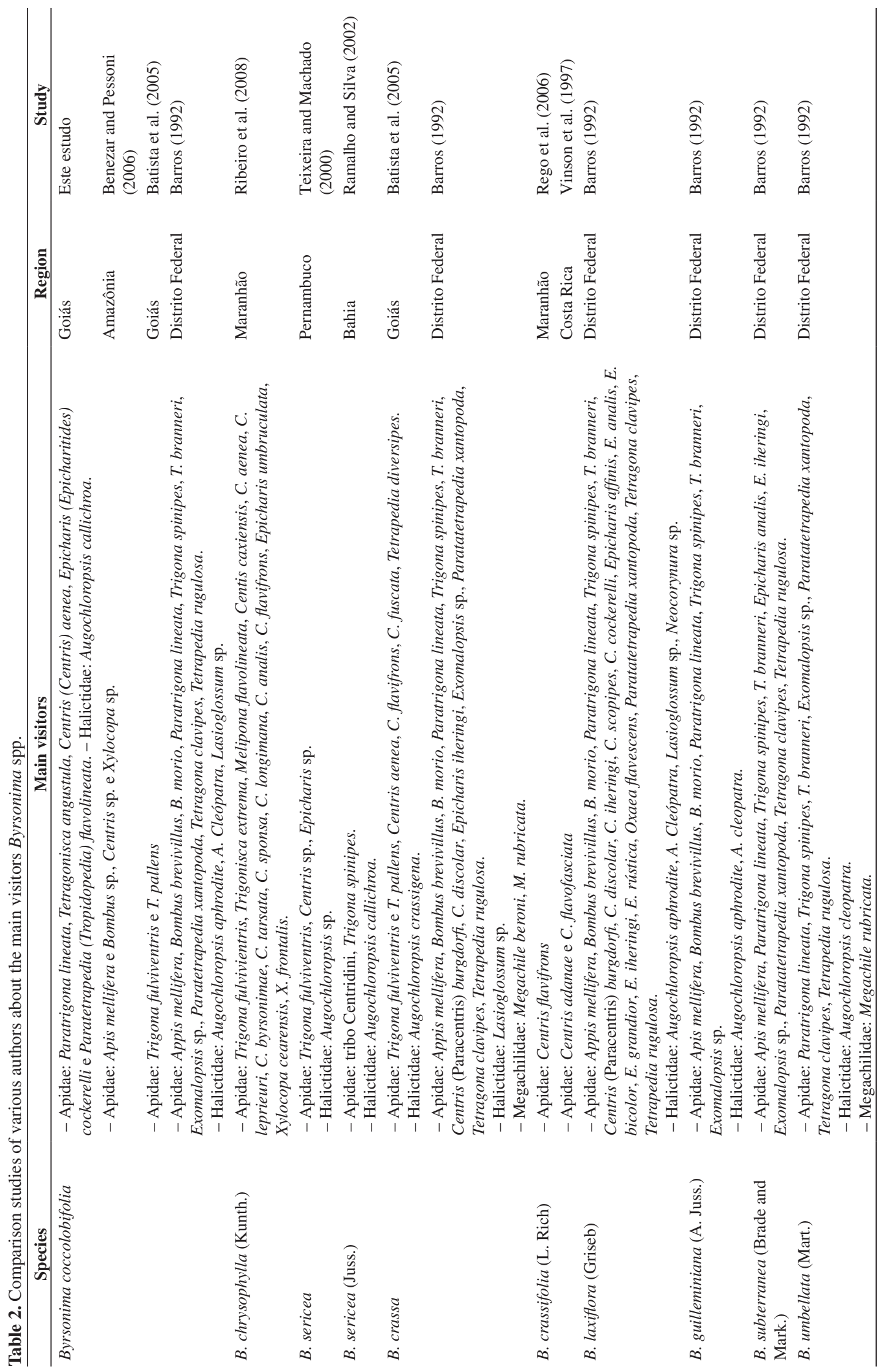


to be more attractive in terms of reward (Duffy and Stout, 2008). Andrieu et al. (2009) claim that the pollinators can adapt their foraging behavior according to the amount of resources available. Gómez et al. (2007) argues that many plants are visited and pollinated by a wide variety of pollinators, thus they may be more likely to suffer Improper Pollen Transfer (IPT), covering the stigma but avoiding effective pollination (Duffy and Stout, 2008).

Another possibility is that the community of pollinators may be in some way impaired, perhaps by a change in the landscape, or the presence of predators, parasites, etc. In resolution of these possible factors that limit crosspollination, self-compatibility becomes an advantage because it increases the likelihood of successful pollination, and can be considerable when failures occur in the absence of pollination or pollinators (Manente-Balestieri and Machado, 1999).

Nevertheless, we do not rule out the possibility of a sampling problem, since the proportion of fruits produced was very low (control branches: $7.2 \%$, and treatment branches: $5.4 \%$ ), especially when compared with other studies (Table 3). Moreover, many branches had broken, lowering the number of samples. The loss in the number of branches may be related to the movement of mammals. Another factor that may result in branch breakage is the heavy rains, common in the region. Whatever the cause is, this may have directly influenced the reproductive success of this plant in the area, which is a factor rarely evaluated in this kind of study.

In the remaining branches, the low fruit set was evident, a factor that was not expected, since the plant has a large number of attractive flowers per inflorescence. It is hard to determine what happened because a lot of factors may influence this result. Many studies, performed on different plants, suggest various hypotheses for low fruiting. Among them are: a shortage or lack of pollinators (Manente-Balestieri and Machado, 1999; Paiva et al., 1999; Kiill and Drumond, 2001; Tavares et al., 2002; Nogueira and Arruda, 2006; Petri et al., 2008), unavailability of nutrients in the soil (Ferreira et al., 2003), herbivory and predation affecting the production and flower or fruit viability (ManenteBalestieri and Machado, 1999; Vieira and Grabalos, 2003; Nogueira and Arruda, 2006; Carvalho et al., 2007; Aguiar and Gaglianone, 2008), lack of resources available on the plant (Manente-Balestieri and Machado, 1999; Vieira and Grabalos, 2003; Nogueira and Arruda, 2006; Carvalho et al., 2007; Aguiar and Gaglianone, 2008), selfpollination, since the species are normally cross-pollinated (Nogueira and Arruda, 2006) and abiotic factors such as temperature, humidity and precipitation (Ferreira et al., 2003; Nogueira and Arruda, 2006; Pereira and Mayer, 2008). Soil characteristics such as $\mathrm{pH}$, aeration, temperature and nutrient availability may also directly affect the plants reproductive success by influencing the production and viability of the fruits (Ferreira et al., 2003).

Some authors point out pollination failure as the main cause for low fruit set (e.g. Kiill and Drummond (2001) in their study of Gliricidia sepium, Tavares et al. (2002) with pears and Paiva et al. (1999) with acerolas). This failure is probably due to the shortage or deficiency of pollinators (Manente-Balestieri and Machado, 1999; Nogueira and Arruda, 2006; Petri et al., 2008). One important possibility is the changing regional landscape. Its conversion to pasture may have a significant effect on the bee population, perhaps due to the loss in nesting sites. This suggests the development of studies in the landscape scale, in which several replicas of landscapes

Table 3. Comparison studies of various authors regarding the production of fruits of Byrsonima spp. in treatments of openpollination and self-pollination.

\begin{tabular}{lccl}
\hline \multicolumn{1}{c}{ Species } & $\begin{array}{c}\text { Open polination } \\
(\boldsymbol{\%})\end{array}$ & $\begin{array}{c}\text { Spontaneous self- } \\
\text { polination (\%) }\end{array}$ & \multicolumn{1}{c}{ Author } \\
\hline B. coccolobifolia & 7,2 & 5,4 & This study \\
& 41,1 & 13,8 & Benezar and Pessoni (2006) - Experiment 1 \\
& 46,6 & 44,0 & Benezar and Pessoni (2006) - Experiment 2 \\
& 20,0 & 0,0 & Batista et al. (2005) \\
B. crassifólia & 33,7 & 10,5 & Barros (1992) \\
B. sericea & 75,0 & - & Pereira and Freitas (2002) \\
B. crassa & 12,0 & 0,0 & Teixeira and Machado (2000) \\
& 36,0 & 4,0 & Batista et al. (2005) \\
B. verbascifolia & 32,3 & 13,3 & Barros (1992) \\
& 42,0 & 4,0 & Batista et al. (2005) \\
B. guilleminiana & 42,3 & 10,0 & Barros (1992) \\
B. laxiflora & 31,7 & 13,6 & Barros (1992) \\
B. subterranea & 53,5 & 5,2 & Barros (1992) \\
B. umbellata & 39,0 & 15,0 & Barros (1992) \\
\hline
\end{tabular}


with different levels of conversion to pasture provide a quantitative evaluation of this hypothesis.

For fruit production, the plant needs a high energy cost, which is often not achieved, promoting high rates of abortion, and therefore low fruit set (Manente-Balestieri and Machado, 1999; Aguiar and Gaglianone, 2008). According to Nogueira and Arruda (2006), abortion of damaged fruits can be an adaptation of the species. This abortion can be compensated with a bigger growth of other fruits. Many plants, even growing in favorable conditions, with adequate pollination, have a considerable percentage of ovules that do not develop. These losses may have a genetic basis because the process of sexual reproduction can produce a high frequency of lethal gene combination in the ovule and pollen (Nogueira and Arruda, 2006).

We must also consider that if the plant predominantly suffers from self-pollination, the chances for fruit abortion are much higher. Accordingly, this high rate of inbreeding leads to an inbreeding depression, which results in a reduced genetic variability, increasing the probability of embryo malformation, so there is a lower probability of persistence (Fuzeto et al., 2001; Nogueira and Arruda, 2006). Or it may simply be a natural process, and the plant should produce this large amount of flowers as a strategy to some fruit persistence.

Acknowledgments - The authors are greatly in debt with the personnel of the Barreiro and Vereda Farms who allowed the experiments and gave logistic support. PDM has a CNPq productivity grant.

\section{References}

AGUIAR, WM. and GAGLIANONE, MC., 2008. Comportamento de abelhas visitantes florais de Lecythis lúrida (Lecythidaceae) no norte do estado do Rio de Janeiro. Revista Brasileira de Entomologia, vol. 52, no. 2, p. 277-282. http://dx.doi.org/10.1590/ S0085-56262008000200007

ANDRIEU, E., DORNIER, A., ROUIFED, S., SCHATZ, B. and CHEPTOU, P., 2009. The town Crepis and the country Crepis: How does fragmentation affect a plant-pollinator interaction? Acta Oecologica, vol. 35, p. 1 - 7. http://dx.doi.org/10.1016/j. actao.2008.07.002

BARROS, MAG., 1992. Fenologia da floração, estratégias reprodutivas e polinização de espécies simpátricas do gênero Byrsonima Rich (Malpighiaceae). Revista Brasileira de Biologia, vol. 52 , no. 2 , p. 343-353.

BATISTA, JA., PACHECO, JFM and SANTOS, LM., 2005. Biologia Reprodutiva de Três Espécies de Byrsonima Rich. Ex Kunth (Malpighiaceae) em um Cerrado Sensu Stricto no Campus da Universidade Estadual de Goiás, Anápolis, Goiás, Brasil. Revista de Biologia Neotropical, vol. 2, no. 2, p. 109-122.

BENEZAR, RMC. and PESSONI, LA., 2006. Biologia floral e sistema reprodutivo de Byrsonima coccolobifolia (Kunth) em uma savana amazônica. Acta Amazonica, vol. 36, no. 2, p. 159-168.

CARVALHO, AT., SANTOS-ANDRADE, FG. and SCHLINDWEIN, C., 2007. Baixo sucesso reprodutivo em Anemopaegma laeve (Bignoniaceae) no Parque Nacional do Catimbau, Pernambuco. Revista Brasileira de Biociências, vol. 5, no. 1, p. 102-104.
CARVALHO, FMV., DE MARCO, P. and FERREIRA, LG., 2009. The Cerrado into-pieces: Habitat fragmentation as a function of landscape use in the savannas of central Brazil. Biological Conservation, vol. 142, p. 1392-1403. http://dx.doi.org/10.1016/j. biocon.2009.01.031

COLLEVATTI, RG., CAPOS, LAO. and SCHOEREDER, JH., 1997. Foraging behaviour of bee pollinators on the tropical weed Triumfetta semitriloba: departure rules from flower patches. Insectes Sociaux, vol. 44, p. 345-352. http://dx.doi.org/10.1007/ s000400050056

COSTANZA, R., D'ARGE, R., GROOT, R., FARBER, S., GRASSO, M., HANNON, B., LIMBURG, K., NAEEM, S., O'NEILL, RV., PARUELO, J., RASKIN, RG., SUTTON, P. and BELT, MVD., 1997. The value of the world's ecosystem services and natural capital. Nature, vol. 387, p. 253-260. http:// dx.doi.org/10.1038/387253a0

CRESSWELL, JE., 1997. Spatial heterogeneity, pollinator behaviour and pollinator-mediated gene flow: bumblebee movements in variously aggregated rows of oil-seed rape. Oikos, vol. 78, p. 546-556. http://dx.doi.org/10.2307/3545616

DE MARCO, P. and COELHO, FM., 2004. Services performed by the ecosystem: forest remnants influence agricultural cultures pollination and production. Biodiversity and Conservation, vol. 13, p. 1245-1255. http://dx.doi.org/10.1023/B:BIOC.0000019402.51193.e8

DUFFY, KJ. and STOUT, JC., 2008. The effects of plant density and nectar reward on bee visitation to the endangered orchid Spiranthes romanzoffiana. Acta Oecologica, vol. 34, p. 13-138.

FAHRIG, L., 1998. When does fragmentation of breeding habitat affect population survival? Ecological Modelling, vol. 105, p. 273-292. http://dx.doi.org/10.1016/S0304-3800(97)00163-4

FERREIRA, MMM., FERREIRA, GB. and FONTES, PCR., 2003. Produção do tomateiro em função de doses de nitrogênio e da adubação orgânica em duas épocas de cultivo. Horticultura Brasileira, vol. 21, no. 3, p. 468-473.

FUZETO, AP., BARBOSA, AAA. and LOMÔNACO C., 2001. Cabralea canjerana subsp. polytricha (Adri. Juss.) Penn. (Meliaceae), uma espécie dióica. Acta Botânica Brasileira, vol. 15 , no. 2, p. 167-175.

GIRALDO-ZUNIGA, AD., ARÉVALO-PINEDO, A., REZENDE, JR., SILVA, CS. and MONTEIRO, JÁ., 2006. Drying Kinetics for Murici (Byrsonima crassifolia) Fruit. Journal of Food Processing and Preservation, vol. 30, p. 699-705. http://dx.doi. org/10.1111/j.1745-4549.2006.00084.x

GÓMEZ, JM., BOSH, J., PREFECTTI, F., FERNÁNDEZ, J. and ABDELAZIZ, M., 2007. Pollinator diversity affects plant reproduction and recruitment: the tradeoffs of generalization. Oecologia, vol. 153, p. 597-605. PMid:17576602. http://dx.doi. org/10.1007/s00442-007-0758-3

GOVERDE, M., SCHWEIZER, K., BAUR, B. and ERHARDT, A., 2002. Small-scale habitat fragmentation effects on pollinator behaviour: experimental evidence from the bumblebee Bombus veteranus on calcareous grasslands. Biological Conservation, vol. 104, p. 293-299. http://dx.doi.org/10.1016/S0006-3207(01)00194-X

KEARNS, CA., INOUYE, DW. and WASER, NM., 1998. Endangered mutualisms: the conservation of plant-pollinator interactions. Annual Review of Ecology and Systematics, vol. 29, p. 83-112. http://dx.doi.org/10.1146/annurev.ecolsys.29.1.83

KIILL, LHP. and DRUMOND, MA., 2001. Biologia floral e sistema reprodutivo de Gliricidia sepium (Jacq.) Steud. (Fabaceae 
- Papilionoidae) na região de Petrolina, Pernambuco. Ciência Rural, vol. 31, no. 4, p. 597-601.

KREMEN, C., WILLIAMS, NM., AIZEN, MA., GEMMILLHERREN, B., LEBUHN, G., MINCKLEY, R., PACKER, L., POTTS, SG., ROULSTON, T., STEFFAN-DEWENTER, I., VÁZQUEZ, P., WINFREE, R., ADAMS, L., CRONE, EE., GREENLEAF, SS., KEITT, TH., KLEIN, AM., REGETZ, J. and RICKETTS, TH., 2007. Pollination and other ecosystem services produced by mobile organisms: a conceptual framework for the effects of land-use change. Ecology Letters, vol. 10, p. 299-314. PMid:17355569. http://dx.doi.org/10.1111/j.14610248.2007.01018.x

LUCK, GW. AND DAILY, GC., 2003. Tropical countryside bird assemblages: richness, composition, and foraging differ by landscape context. Ecological Applications, vol. 13, no. 1, p. $235-247$

MANENTE-BALESTIERI, FCDL. and MACHADO, VLL., 1999. Entomofauna Visitante das Flores de Cassia spectabilis (L.) D C. (Leguminosae). In Anais da Sociedade Entomológica do Brasil, 1999. Rio Claro. p. 492-437.vol. 28, no. 3.

NAEEM, S., CHAIR, FSC., CONSTANZA, R., EHRKICH, PR., GOLLEY, FB., HOOPER, DU., LAWTON, JH., O`NEILL, RV., MOONEY, HA., SALA, OE., SYMSTAD, AJ. and TILMAN, D., 1999. Biodiversity and Ecosystem Functioning: Maintaining Natural Life Support Processes. Issues in Ecology, no. 4, p. 11.

NOGUEIRA, EML. and ARRUDA, VLV., 2006. Frutificação e danos em frutos e sementes de Sophora tomentosa L. (Leguminosae, Papilionoideae) em restinga da praia da Joaquina, Florianópolis, SC. Biotemas, vol. 19, no. 4, p. 41-48.

NOMIYAMA, DH., MARCON, G., REIS, LF. and NETO, PB., 2000. Agricultura Sustentável - Ministério do Meio Ambiente (MMA). Brasília: Editora Ibama. 190 p.

PAIVA, JR., PAIVA, WO., CORDEIRO, ER. and NETO, HS., 1999. Parâmetros Genéticos em Progênies de Polinização Livre de Acerola. Pesquisa Agropecuária Brasileira, vol. 34, no. 4, p. 629-634.

PEREIRA, FM. and MAYER, NA., 2008. Frutificação, características físicas de frutos e produtividade em cultivares e seleções de pessegueiro em Vista Alegre do Alto-SP. Ciência Rural, vol. 38 , no. 6, p. 1547-1552.

PEREIRA, JOP. and FREITAS, BM., 2002. Estudo da Biologia Floral e Requerimentos de Polinização do Muricizeiro (Byrsonima crassifolia L.). Revista Ciência Agronômica, vol. 33, no. 2, p. 55-60.

PERFECTO, I. and VANDERMEER, J., 2002. Quality of agroecological matrix in a tropical montane landscape: Ants in coffee plantations in southern Mexico. Conservation Biology, vol. 16 , no. 1 , p. $174-182$

PETRI, JL., HAWERROTH, FJ. and LEITE, GB., 2008. Fenologia de Espécies Silvestres de Macieira como Polinizadoras das Cultivares Gala e Fuji. Revista Brasileira de Fruticultura, vol. 30, no. 4, p. 868-874.

RAMALHO, M. and SILVA, M., 2002. Flora Oleífera e sua Guilda de Abelhas em uma Comunidade de Restinga Tropical. Sitientibus Série: Ciências Biológicas, vol. 2, no. 1/2, p. 34-43.

REGO, MMC., ALBUQUERQUE, PMC., RAMOS, MC. and CARREIRA, LM., 2006. Aspectos da Biologia de Nidificação de Centris flavifrons (Friese) (Hymenoptera: Apidae, Centridini), um dos Principais Polinizadores do Murici (Byrsonima crassifolia L.
Kunth, Malpighiaceae), no Maranhão. Neotropical Entomology, vol. 35 , no. 5 , p. $579-587$.

REZENDE, CM. and FRAGA, SRG., 2003. Chemical and Aroma Determination of the Pulp and Seeds of Murici (Byrsonima crassifolia L.). Journal of the Brazilian Chemical Society, vol. 14, no. 3, p. 425-428.

RIBEIRO, EKMD., RÊGO, MMC. and MACHADO, ICS., 2008. Cargas polínicas de abelhas polinizadoras de Byrsonima chrysophylla Kunth. (Malpighiaceae): fidelidade e fontes alternativas de recursos florais. Acta Botânica Brasileira, vol. 22, no. 1, p. 165-171.

RIBEIRO, LF. and TABARELLI, M., 2002. A structural gradient in Cerrado vegetation of Brazil: changes in woody plant density, species richness, life history and plant composition. Journal of Tropical Ecology, vol. 18, p. 775-794.

RICKETTS, TH., 2004. Tropical Forest Fragments Enhance Pollinator Activity in Nearby Coffee Crops. Conservation Biology, vol. 18, no. 5, p. 1262-1271. http://dx.doi.org/10.1111/j.15231739.2004.00227.x

SANO, SM. and ALMEIDA, SP., 1998. Cerrado: Ambiente e Flora. Planaltina: Embrapa. 556 p.

SANTOS, TE., NOGUERA, F., PIRES, JSR., OBARA, AT. and PIRES, AMZCR., 2001. The Value Of The Ecological Station Of Jataí's Ecosystem Services And Natural Capital. Revista Brasileira de Biologia, vol. 61, no. 2, p. 171-190.

SILVEIRA, FA., MELO, GAR. and ALMEIDA, EAB., 2002. Abelhas Brasileiras - Sistemática e Identificação. 1nd ed. Belo Horizonte: Fernando A. Silveira. 253 p.

TABARELLI, M., SILVA, JMC. and GASCON, C., 2004. Forest fragmentation, synergisms and theimpoverishment of neotropical forests. Biodiversity and Conservation, vol. 13, p. 1419-1425. http://dx.doi.org/10.1023/B:BIOC.0000019398.36045.1b

TAVARES, JC., FACHINELLO, JC., DA SILVA, JB. and HERTE, FG., 2002. Fitorreguladores no aumento da frutificação efetiva e partenocarpia em peras CV. Garber. Revista Brasileira de Fruticultura, vol. 24, no. 3, p. 629-630.

TEIXEIRA, LAG. and MACHADO, IC., 2000. Sistema de polinização e reprodução de Byrsonima sericea DC. (malpighiaceae). Acta Botânica Brasílica, vol. 14, p. 347-357.

VANDERMEER, J. and PERFECTO, I., 2006. The Agricultural Matrix and a Future Paradigm for Conservation. Conservation Biology, vol. 21, no. 1, p. 274-277. PMid:17298536. http://dx.doi. org/10.1111/j.1523-1739.2006.00582.x

VIEIRA, MF. and GRABALOS, R., 2003. Sistema reprodutivo de Oxypetalum mexiae Malme (Asclepiadaceae), espécie endêmica de Viçosa, MG, Brasil, em perigo de extinção. Acta Botânica Brasilica, vol. 17, no. 1, p. 137-145.

VINSON, SB., WILLIAMS, HJ., FRANKIE, GW. and SHRUM, G., 1997. Floral Lipid Chemistry of Byrsonima crassifolia (Malpigheaceae) and a Use of Floral Lipids by Centris Bees (Hymenoptera: Apidae). Biotropica, vol. 29, no. 1, p. 76-83. http://dx.doi.org/10.1111/j.1744-7429.1997.tb00008.x 
